\title{
DAMPAK MEDIA SOSIAL TERHADAP PERILAKU SOSIAL ANAK DI KOTA MAKASSAR
}

\author{
Sam'un Mukramin \\ Pendidikan Sosiologi, Universitas Muhammadiyah Makassar \\ Email: sam'unmukramin@unismuh.ac.id
}

\begin{abstract}
The main problem in this study is the intensity of the use of communication media by children who are considered to have a very strong interest in character building and child protection. The media provides information and knowledge which in turn can create perceptions of influencing and influencing children in Makassar City. This type of research is qualitative research. Data collection techniques are observation, interviews, and documentation. Data analysis techniques are recorded, collecting data and thinking so that categories have meaning. The technique used in selecting and determining research subjects is, the Snowball Sampling Technique. The snowball sampling technique is a method for selecting, selecting and taking samples in a network or relationship that is made. The results of research with the object of research on children's social and communication media in the city of Makassar, can conclude that communication media has become something that is needed by the community, from upper class to lower class. Communication media is no longer a difficult thing to obtain. Communication media has also spread to all circles and ages as evidenced by the widespread use of communication media in the community with adolescents and children. It is undeniable because children and adolescents are most vulnerable to being caught in the bad influence of the media. Using communication media not only has a positive impact, but also has a negative impact that can affect users earlier than children who are fast and have a high curiosity. Enabling children to access something negative or not good and not appropriate to the age of the child, this can cause their performance to improve. In this case, the role of parents is very important in the process of supervision and provides an understanding of children in the use of communication media wisely so that things that do not need to be done on adolescents and children, because encouraging parents is the first institution in forming mindset, behavior, and character of the child.
\end{abstract}

Keywords: Social Behavior, Communication Media

\begin{abstract}
Abstrak. Masalah utama dalam penelitian ini adalah intensitas penggunaan media komunikasi oleh anak-anak dianggap mempunyai pengaruh yang sangat kuat terhadap pembentukan karakter dan perilaku anak. Media memberikan informasi dan pengetahuan yang pada akhirnya dapat membentuk persepsi sehingga mempengaruhi sikap dan perilaku seorang anak di Kota Makassar. Jenis penelitian yang dilakukan adalah penelitian kualitatif. Teknik pengumpulan data yaitu observasi, wawancara, dan dokumentasi. Teknik analisis data yaitu mencatat, pengumpulan data dan berpikir agar kategori data mempunyai makna. Teknik yang digunakan dalam memilih dan menentukan subjek penelitian yaitu, Teknik Sampling Snowball. Teknik Sampling snowball adalah suatu metode untuk mengidentifikasi, memilih dan mengambil sampel dalam suatu jaringan atau rantai hubungan yang menerus. Hasil penelitian dengan objek penelitian perilaku sosial anak dan media komunikasi di kota Makassar, dapat kesimpulkan bahwa media komunikasi telah menjadi sesuatu yang sangat di butuhkan oleh masyarakat, dari masyarakat kelas atas sampai kelas bawah. Media komunikasi bukan lagi hal yang susah untuk diperoleh. Media komunikasi juga telah merambat pada kalangan semua kalangan dan usia dibuktikan dari maraknya penggunaan media komunikasi di lingkungan masyarakat bahkan remaja dan anak-anak. Tidak bisa dipungkiri bahwa anak-anak dan remaja paling rentan terjebak dalam pengaruh buruk media. Penggunaan media komunikasi tidak hanya memberikan dampak positif saja, akan
\end{abstract}


tetapi juga memberikan dampak yang negatif yang dapat merugikan penggunanya terlebih pada anak yang cepat terpengaruh dan memiliki rasa ingin tahu yang tinggi. Sehingga secara tidak langsung remaja atau anakanak dapat mengakses sesuatu hal yang negatif atau yang tidak baik dan tidak sesuai dengan umur sang anak, ini dapat menyebabkan prestasi mereka menurun. Dalam hal ini maka peran orang tua sangat lah penting dalam melakukan proses pengawasan dan memberikan pemahaman kepada anak dalam penggunaan media komunikasi dengan bijak sehingga hal-hal yang tidak di inginkan tidak terjadi pada remaja dan anak-anak, karena mengingat orang tua adalah lembaga pertama dalam pembentukan pola pikir, perilaku, dan karakter anak.

Kata Kunci: Perilaku Sosial, Media Komunikasi

\section{PENDAHULUAN}

Dalam kehidupan bermasyarakat banyak perubahan dan penemuan baru yang kita jumpai yang semakin hari semakin beragam, dari kebutuhan primer, sekunder dan tersier, hal tersebut menyesuaikan diri dengan kebutuhan hidup masyarakat, perubahan dan penemuan tersebut meliputi hal-hal yang berskala kecil hingga skala yang sangat besar dan selalu berubah setiap harinya, hal ini jelas sudah tidak bisa dihindari lagi, yang secara tidak langsung akan menyebabkan perubahan struktur dan pola dalam masyarakat itu sendiri. Perubahan sosial merupakan perubahan kepada pola perilaku, hubungan sosial, lembaga, dan struktur sosial pada waktu tertentu. Ini menunjukan bahwa dalam masyarakat terjadi perubahan interaksi antara satu dengan yang lain ketika merea melakukan tindakan dan perbuatan atas apa yang dilakukan (Sztompka, 2004).

Perubahan-perubahan ini tidak hanya dapat kita jumpai pada masyarakat perkotaan saja akan tetapi perubahan-perubahan ini telah merambah juga pada kehidupan masyarakat di daerah pedesaan dengan alasan kebutuhan hidup masyarakat. Peruabahan yang paling mencolok yang sering kita jumpai adalah perubahan pada sektor teknologi informasi dan komunikasi. Dalam kehidupan masyarakat modern perkembangan teknologi dan media komunikasi semakin hari semakin pesat seperti semakin meluasnya penggunaan internet dan handphone. Penggunaan internet dan media komunikasi di dalam kehidupan pribadi sekarang semakin marak, ditandai dengan setiap orang setidaknya memiliki satu teknologi media komunikasi. Hal ini paling banyak dan dapat kita jumpai diseluruh di daerah khususnya daerah perkotaan.

Penggunaan media komunikasi di era modern tidak lagi susah dijumpai, bahkan semua kalangan sudah memiliki teknologi komunikasi. Hal ini menandakan sudah tidak lagi susah mendapatkan media komunikasi ini. Media komunikasi yang paling banyak di gunakan adalah telepon seluler atau handphone, hal ini disebabkan karena media komunikasi ini lebih mudah dan praktis untuk digunakan maupun dibawa kemana-mana dan mudah dioperasikan dan juga dari segi manfaatnya, sehingga manusia lebih banyak yang menggunakan media komunikasi ini, Media komunikasi ini juga memiki berbagai fitur yang membantu manusia dalam melakukan aktifitasnya.

\section{a. Media Sosial}

Meike dan Young dalam Nasrullah (2015) mengartikan kata media sosial sebagai konvergensi antara komunikasi personal dalam arti saling berbagi diantara individu (to be share one-to-one) dan media publik untuk berbagi kepada siapa saja tanpa ada kekhususan individu.

Van Dijk dalam Nasrullah (2015) menyatakan bahwa media sosial adalah platform media yang memfokuskan pada eksistensi pengguna yang memfasilitasi mereka dalam beraktifitas maupun berkolaborasi. Karena itu media sosial dapat dilihat sebagai medium (fasilitator) online yang menguatkan hubungan antar pengguna sekaligus sebuah ikatan sosial.

Pada dasarnya media sosial, merupakan seprangkat alat teknologi yang mampu mengkolaborasi berbagai aktivitas manusia, khususnya dalam hal kecepatan, ketepatan, dan mengarah pada efesiensi dan mampu merubah kepribadian manusia baik secara individu maupun 
kelompok/komunitas sehingga memproduksi karakter sendiri sesuai keinginan pengguna media tersebut melalui network.

\section{b. Karakteristik dan Perkembangan Media Sosial}

Karakteristik media sosial tidak jauh berbeda dengan media siber (cyber) dikarenakan media sosial merupakan salah satu platform dari media siber. Namun demikian, menurut Nasrullah (2015) media sosial memiliki karakter khusus, yaitu: Jaringan (Network), Jurnal online (blog), Jurnal online sederhana atau microblog (micro-blogging), Media berbagi (media sharing), Penanda sosial (social bookmarking) dan Media konten bersama atau wiki.

Perkembangan media komunikasi tidak hanya merambat pada usia-usia tertentu saja akan tetapi sudah merambat di semua kalangan maupun usia, dari yang muda sampai yang tua, sehingga media komunikasi dan teknologi sekarang telah menjadi sahabat bagi anak, dan mengurangi minat untuk bermain dan belajar, apalagi untuk konten yang tidak baik, seperti kekerasan (game dan film) serta pornografi, dipercaya mempengaruhi secara negatif baik perilaku anak dan kemampuan anak. Mereka menjadi peniru yang handal. Mereka lebih pintar dari yang kita pikir, lebih cerdas dari yang terlihat, sehingga jangan meremehkan anak pada usia tersebut. Jika Anak-anak sudah diberikan media komunikasi dan teknologi sebagai mainan, maka itu akan berpengaruh terhadap proses pemerolehan bahasanya dan yang lebih mengkhawatirkan adalah gangguan pada perkembangan emosi sang anak, hal ini menyebabkan anak-anak yang tingkat penggunaan medianya tinggi, interaksi sosialnya bersifat tak langsung atau bermedia, sosiabilitasnya cenderung rendah, kepekaan sosialnya cenderung rendah, cenderung agresif, sehingga perkembangan yang kian pesat di bidang teknologi dan komunikasi tersebut, perkembangan jiwa anakpun mengalami perubahan yang perlu di perhatikan. Kegemaran bermain dengan media baru ini yang berlebihan akan menyebabkan kurangnya hubungan sosial anak dengan teman-temannya sehingga dapat menghambat kemampuan berpikir dan bersosialnya.

Dalam kehidupan anak, penggunaan media komunikasi sebagai bagian dari teknologi informasi, media komunikasi ibarat pisau bermata dua. Di satu sisi, hal ini bisa bermanfaat apabila digunakan untuk melakukan hal-hal yang baik dan bermanfaat, seperti mencari bahan-bahan pelajaran sekolah, diskusi mata pelajaran, belajar jarak jauh, dan mencari metode-metode pengajaran berbasis multimedia. Namun di lain sisi penggunaan media komunikasi juga dapat mengarah kepada hal-hal negatif yang kemudian mempengaruhi perilaku sosial anak. Intensitas penggunaan media komunikasi oleh anak-anak dianggap mempunya pengaruh yang sangat kuat terhadap pembentukan karakter dan perilaku anak. Media memberikan informasi dan pengetahuan yang pada akhirnya dapat membentuk persepsi sehingga mempengaruhi sikap dan perilaku seseorang.

Hurlock, B. Elizabeth mengatakan bahwa "Perilaku sosial adalah aktifitas fisik dan psikis seseorang terhadap orang lain atau sebaliknya dalam rangka memenuhi diri atau orang lain yang sesuai dengan tuntutan sosial". Yang dimaksud Perilaku sosial adalah Perilaku ini tumbuh dari orangorang yang ada pada masa kecilnya mendapatkan cukup kepuasan akan kebutuhan inklusinya. la tidak mempunyai masalah dalam hubungan antar pribadi mereka bersama orang lain pada situasi dan kondisinya. la bisa sangat berpartisipasi, tetapi bisa juga tidak ikutikutan, ia bisa melibatkan diri pada orang lain, bisa juga tidak, secara tidak disadari ia merasa dirinya berharga dan bahwa orang lain pun mengerti akan hal itu tanpa ia menonjolkan-nonjolkan diri. Dengan sendirinya orang lain akan melibatkan dia dalam aktifitas-aktifitas mereka. Walgito mengatakan perilaku manusia tidak lepas dari keadaan individu itu sendiri dan lingkungan dimana individu itu berada. Perilaku Sosial adalah aktifitas fisik dan psikis seseorang terhadap orang lain atau sebaliknya dalam rangka memenuhi diri atau orang lain yang sesuai dengan tuntutan sosial. Perilaku sosial adalah suasana saling ketergantungan yang merupakan keharusan untuk menjamin keberadaan manusia, artinya bahwa kelangsungan hidup manusia berlangsung dalam suasana saling mendukung dalam kebersamaan. (Rusli Ibrahim 2001). 


\section{METODE PENELITIAN}

Jenis penelitian yang digunakan adalah penelitian kualitatif deskriptif. Penelitian deskriptif kualitatif adalah suatu proses penelitian yang menghasilkan deskripsi dari orang-orang atau perilaku dalam bentuk kata-kata baik lisan maupun tulisan. Salah satu ciri penelitian kualitatif adalah bersifat deskriptif di mana data dikumpulkan dalam bentuk kata-kata, gambaran dan bukan angka. Metode penelitian kualitatif ini juga sering disebut metode penelitian naturalistik, karena penelitiannya dilakukan pada kondisi yang alamiah (natura Isetting), (Sugiyono, 2013: 89). Jenis pendekatan yang digunakan dalam penelitian ini adalah studi kasus. Studi kasus merupakan strategi penelitian dimana di dalamnya peneliti menyelidiki secara cermat suatu program, peristiwa, aktivitas, proses, atau sekelompok individu. Kasus-kasus dibatasi oleh waktu dan aktivitas, dan peneliti mengumpulkan informasi secara lengkap dengan menggunakan berbagai prosedur pengumpulan data berdasarkan waktu yang telah ditentukan. Adapun subjek yang menjadi informan dalam penulisan ini yaitu anakanak dan remaja yang menggunakan media komunikasi dan para orang tua yang memiliki anak yang menggunakan media komunikasi. Teknik yang digunakan dalam memilih dan menentukan subjek penelitian yaitu, Teknik Sampling Snowball. Teknik snowball sampling adalah suatu metode untuk mengidentifikasi, memilih dan mengambil sampel dalam suatu jaringan atau rantai hubungan yang menerus. Pada pelaksanaannya, teknik snowball sampling adalah suatu teknik yang multitahapan, didasarkan pada analogi bola salju, yang dimulai dengan bola salju yang kecil kemudian membesar secara bertahap karena ada penambahan salju ketika digulungkan dalam hamparan salju. Dalam penelitian ini ada dua jenis informan yang digunakan dalam penelitian, yaitu informan pertama dari anak-anak dan remaja yang menggunakan media komunikasi, sedangkan informan kedua dari orang tua anak-anak dan yang menggunakan media komunikasi yang ada di Kota Makassar. Teknik pengumpulan data yaitu observasi, wawancara, dan dokumentasi. Teknik analisis data yaitu mencatat, pengumpulan data dan berpikir agar kategori data mempunyai makna.

\section{HASIL DAN PEMBAHASAN}

Media komunikasi ini sangat membantu dalam proses kehidupan dalam masyarakan, menjadikan segala sesuatu menjadi lebih praktis dan cepat dalam memperoleh informasi dan berita tanpa harus dibatasi jarak dan waktu, hal ini sejalan dengan apa yang di sampaikan oleh McLuhan, seorang ahli filsafat dari teori komunikasi yang merupakan seorang teknologi determinis yang memiliki pandangan mengenai teknologi sebagai suatu perpanjangan dari manusia dan kebutuhannya, dan teknologi yang selama ini dibuat bermaksud untuk mempermudah semua kegiatan manusia, dan perpanjangan dari panca indra manusia.

\section{a. Media Komunikasi dan Perubahan Sosial}

Perubahan sosial merupakan perubahan-perubahan yang terjadi pada lembaga-lembaga kemasyarakatan dalam masyarakat yang mempengaruhi sistem sosialnya, termasuk nilai, sikap-silap sosial, dan pola perilaku di antara kelompok kelompok masyarakat, terlebih dalam kehidupan masyarakat perkotaan yang semakin berkembang mngikuti perkembangan zaman.

Teori Determinisme teknologi menegaskan bahwa perubahan yang terjadi dalam perkembangan teknologi sejak zaman dahulu sampai saat ini memberikan pengaruh yang besar terhadap masyarakat. Perkembangan teknologi seperti reka baru atau bisa juga disebut inovasi, penemuanpenemuan baru, dan hal-hal lain yang bertujuan mengembangkan teknologi untuk mempermudah kegiatan-kegiatan manusia, memberikan pengaruh yang besar kepada perkembangan nilai-nilai sosial dan kehidupan dalam masyarakat.

Determinisme teknologi juga diartikan sebagai suatu susunan otonom yang berbasis teknologis yang kemudian mengklaim bahwa teknologi sebagai suatu faktor yang dominan dari terjadinya perubahan-perubahan sosial yang pengaruhnya sendiri berangkat dari makna kebudayaan dan kegunaan yang bisa diberikan oleh teknologi tersebut, sebab pada dasarnya dalam determinisme teknologi, inovasi yang ditemukan oleh para penemu di dalam masyarakat juga ditujukan untuk 
masyarakat. Maka dari itu, determinisme teknologi menganggap pentingnya ide-ide manusia dalam menciptakan teknologi yang kemudian teknologi tersebut mempengaruhi kehidupan sosial manusia.

Dari uraian tersebut, jelas media komunikasi dan teknologi telah menjadi salah satu pendorong perubahan sosial dalam kehidupan masyarakat dan menjadikannya lebih praktis juga sangat dibutuhkan oleh masyarakat di era modern seperti sekarang.

\section{b. Perilaku Sosial Anak}

Perilaku sosial seseorang tampak dalam pola respon antar orang yang dinyatakan dengan hubungan timbal balikantar pribadi, perilaku sosial juga identik dengan reaksi seseorang terhadap orang lain, perilaku itu di tunjukan dengan perasaan, tindakan, sikap keyakinan, kenangan atau rasa hormat terhadap orang lain. Perilaku sosial bersifat relatif untuk menanggapi orang lain dengan cara-cara yang berbeda. Pembentukan perilaku sosial seseorang dipengaruhi oleh berbagai faktor. Tanpa kita sadari media komunikasi juga telah mengambil alih dalam proses pembentukan perilaku sosial anak dalam penggunanaan media komunikasi.

Demikian, media komunikasi memberikan pengaruh dalam proses interaksi sosial serta hubungan sosial yang dilakukan oleh individu dengan individu lainnya. Sehingga media komunikasi ini memberikan perubahan pada perilaku sosial pada anak.

\section{Dampak yang ditimbulkan oleh Media Komunikasi Terhadap Perilaku Sosial Anak di Kota Makassar}

Kemajuan teknologi saat ini tidak dapat dipisahkan dari kehidupan masyarakat. Berbagai informasi yang terjadi di berbagai belahan dunia kini telah dapat langsung kita ketahui berkat kemajuan teknologi komunikasi ini. Saat ini dunia sudah terasa semakin sempit karena cepatnya akses informasi diberbagai dunia seolah semakin sempit dikarenakan kita dapat melihat apa yang terjadi di belahan dunia lainnya lewat perkembangan teknologi dan media komunikasi.

Media komunikasi merupakan salah satu hasil perkembangan teknologi yang diciptakan dalam bentuk perangkat kecil yang penggunaannya semakin meningkat karena kemajuan teknologi dan media komunikasi. Tentu kemajuan teknologi ini menyebabkan terjadinya perubahan besar pada kehidupan masyarakat dan segala peradaban. Perubahan ini juga memberikan dampak yang begitu besar terhadap nilai-nilai yang ada di kehidupan masyarakat. Dalam kehidupan dapat kita saksikan begitu besar pengaruh kemajuan teknologi dan media komunikasi terhadap nilai-nilai yang dianut oleh masyarakat. Kemajuan teknologi dan media komunikasi seperti televisi, telepon dan telepon genggam (hp), bahkan internet yang bukan saja melanda masyarakat kota saja akan tetapi sudah dapat dinikmati oleh masyarakat pedesaan, Jika dipandang dari harga, media komunikasi bukanlah barang yang murah sehingga hanya digunakan oleh orang-orang yang berkepentingan saja, tetapi faktanya anak-anak dan remaja pun sudah menggunakannya. Akibatnnya, segala informasi baik itu yang positif atau yang negatif dapat di akses dengan mudah.

Media komunikasi memiliki dampak terhadap anak. Dari hal tersebut dapat di golongkan menjadi 2 gologan, yaitu dampak positif dan dampak negatif.

\section{a) Dampak Positif}

1) Anak-anak dapat menggunakan perangkat lunak seperti program-program pengetahuan untuk menambah wawasan.

2) Membuat anak-anak lebuh tertarik untuk belajar

3) Memudahkan anak-anak untuk mendapatkan lebih banyak ilmu tambahan lewat internet yang di akses melalui media komunikasi.

\section{b) Dampak Negatif}

1) Anak-anak bisa ketergantungan dengan teknologi dan media komunikasi.

2) Anak-anak cenderung mengrjakan tugas sediri dengan bantuan internet dari pada belajar kelompok.

3) Dapat berpengaruh pada pergaulan karena kurang kontrol dari orang tua 
4) Anak-anak bisa bebas dalam mengakses semua situs-situs yang tidak baik

5) Mengurangi sifat sosial manusia karena cenderung lebih suka berhubungan lewat internet atau melalui media dari pada bertemu secara langsung.

6) Kemungkinan besar anak-anak tanpa sepengetahuan orang tua dapat mngakses gamesgames yang mengandung unsur-unsur kekerasan dan agresivitas.

7) media komunikasi memberi banyak manfaatnya bagi kehidupan kalau digunakan secara bijak, seperti membantu dalam proses belajar. Selain itu Media komunikasi dikalangan anak-anak juga memberi dampak yang negatif, seperti membuat anak-anak menjadi malas belajar, merasa ketergantungan dengan media komunikasi handphone (HP), dan dampak yang paling bahaya dari penggunaan media komunikasi ini yaitu merusak kesehatan mata karena terlalu sering memandangi layar HP, komputer, dan televisi. maka dari itu dalam mengurangi dampak dari penggunaan media komunikasi ini perlu adanya pengawasan dari orang tua.

\section{Peran Orang Tua Terhadap Perilaku Sosial Anak dalam Penggunaan Media Komunikasi di Kota Makassar}

Perkembangan teknologi dan media komunikasi bagai pisau bermata dua. Manfaat yang dihasilkan selaras dengan ancaman bahaya yang mungkin di timbulkan apabila digunakan dengan tidak semestinya. Zaman sekarang, anak-anak menikmati waktu senggangnya tidak lagi bermain masak-masak atau main mobil-mobilan seperti anak-anak pada zaman terdahulu. Anak-anak zaman sekarang sudah disibukkan dengan media komunikasi atau handphone nya masing-masing atau istilah populernya itu gadged. Mulai dari menonton vidio dari youtube, bermain games, sampai asik mengotak-atik media sosial mereka sepert Instagram, Facebook, WhatsAap dan media sosial lainnya. Rata-rata mereka menggunakan media komunikasinya untuk meposting foto ke media sosial atau bermain games. Akan tetapi media komunikasi bisa menjadi bumerang atau senjata yang bisa berdampak negatif bagi anak-anak. Dalam hal ini sangat di perlukan peran orang tua dalam mengawasi anak-anaknya terhadap penyalah gunaan media komunikasi ini.

Sebagai orang tua, harus pandai memahami atau mengontrol tentang teknologi terlebih pada penggunaan dan fungsi media komunikasi itu sendiri, apalagi teknologi atau media yang digunakan oleh anak-anak yang tak terbendung akibat derasnya modernisasi saat ini yang mengarah pada perubahan perilaku individu terlebih lagi pada anak berusia remaja sebagaimana dikatakan oleh Mukramin dan Suardi (2017) bahwa pengaruh dari arus modernisasi dan globalisasi yang telah merambah ke semua aspek kehidupan sosial masyarakat, menjadikan masyarakat mengalami perubahan yang signifikan yang berefek pada kepribadian individu. Oleh karena itu, orang tua berperan penting dan memiliki tanggung jawab penuh pada proses dan perkembangan anak, sehingga denga hal tersebut orang tua bisa memantau anaknya dari dunia digital.

Orang tua memiliki peran dan fungsi dalam keluarga terhadap anak sebagai berikut :

a) Fungsi Sosialisasi Anak

Fungsi sosialisasi menunjuk pada peranan keluarga dalam membentuk kepribadian anak. Melalui fungsi ini, keluarga berusaha mempersiapkan bekal selengkap-lengkapnya kepada anak dengan memperkenalkan pola tingkah laku, sikap keyakinan, cita-cita, dan nilai-nilai yang dianut oleh masyarakat serta mempelajari peranan yang diharapkan akan dijalankan oleh mereka. Dengan demikian, sosialisasi berarti melakukan proses pembelajaran terhadap seorang anak.

b) Fungsi Afeksi

Salah satu kebutuhan dasar manusia adalah kebutuhan kasih sayang atau rasa cinta. Pandangan psikiatrik mengatakan bahwa penyebab utama gangguan emosional, perilaku bahkan kesehatan fisik adalah ketiadaan cinta, yakni tidak adanya kehangatan dan hubungan ksih sanyang dalam suatu lingkungan yang intim.

c) Fungsi Edukatif 
Keluarga merupakan guru pertama dalam mendidik anak. Hal itu dapat dilihat dari pertumbuhan seorang anakmulai dari bayi, belajar berjalan, hingga mampu berjalan.

d) Fungsi Religius

Dalam masyarakat indonesia dewasa ini fungsi di keluarga semakin berkembang, diantaranya fungsi keagamaan yang mendorong di kembangkannya keluarga dan seluruh anggota keluarga menjadi insan-insan agama yang penuh dengan keimanan dan ketakwaan kepada tuhan yang maha esa.

e) Fungsi Protektif

Keluarga merupakan tempat yang nyaman bagi para anggotanya. Fungsi ini bertujuan agar para anggota keluarga dapat terhindar dari hal-hal yang negatif. Dalam setiap mesyarakat lekuarga memberikan perlindungan fisik, ekonomis, dan psikologis bagi seluruh anggota.

f) Fungsi Rekreatif

Fungsi ini bertujuan untuk memberikan suasanan yang sangat gembira dalam lingkungan. Fungsi rekreatif dijadikan untuk mencari hiburan. Dewasa ini, tempat hiburan yang banyak berkembangan diluar rumah karena fasilitas dan aktifitas rekreasi berkembang dengan pesatnya.

g) Fungsi Penemuan Status

Dalam sebuah keluarga, sesorang menerima serangkaian status berdasarkan umur, urutankelahiran, dan sebagainya. Status/kedudukan ialah suatu pringkat atau posisi seseorang dalam suatu kelompok dalam hubungannya dengan kelompok lainnya. Pola bimbingan orang tua pada anak selain bimbingan di sekolah, bimbingan di rumah sangat penting, karena anak lebih banyak menghabiskan waktunyadi lingkungan keluarga. Untuk itu keluarga dan orang tua dituntut untuk dapat menerapkan pendidikan keimanan guna sebagai pegangan anak di masa depan.

Pengaruh media terhadap perkembangan anak sangatlah besar apa lagi di zaman yang kian hari kian berkembang. Dengan demikian, penting bagi semua pihak terkhusus orang tua untuk menjelaskan dan memaparkan pada anak tentang panduan penggunaan media komunikasi yang sesuai denga usia, termasuk televisi, radio, musik, permainan, vidio dan penggunaan internet. Hal ini untuk mengekplorasi efek manfaat dan bahaya dari media kominikasi.

Dalam beradaptasi dan mengaplikasikan teknologi-teknologi baru yang muncul di masyarakat yang memang diciptakan untuk mempermudah kehidupan manusia, akan terjadi pergeseranpergeseran nilai-nilai, kebiasaan, cara berinteraksi, cara berkomunikasi, serta sistem-sistem yang ada di masyarakat yang tentu akan membawa dampak yang paling jelas seperti perubahan sosial yang mencakup perubahan secara keseluruhan.

Tanpa disadari teknologi telah mengubah kehidupan sosial masyarakat pada umumnya. Interaksi sosial yang selama ini biasa mereka lakukan menghilang. Tiap individu tidak lagi lebih akrab dengan individu lain. Mereka lebih akrab dengan media komunikasinya (handphone). Banyak sebagian besar anak-anak dan remaja yang lebih memilih bermain game di rumah masing-masing dibandingkan dengan memainkan permainan tradisional di luar rumah. Teknologi telah mengubah ikatan sosial antar individu dengan masyarakat luas.

Dari hasil pengamatan yang dilakukan di Kota Makassar mengenai media komunikasi dan perilaku sosial anak bahwa media komunikasi membawa perubahan-perubahan terhadap pola interaksi dan pola perilaku anak. Salah satu contoh yang bisa kita lihat adalah ketika seorang anak mulai menggunakan media komunikasi maka dapat kita lihat perubahan-perubahan yang terjadi seperti anak mulai disibukkan oleh media komunikasi tersebut entah itu hanya sekedar mendengarkan musik, teleponan, menonton, bermain game, ataupun belajar. Hal ini disebabkan teknologi media komunikasi ini tidak lagi susah di akses atau di gunakan bahkan didapatkan, dari halhal tersebut maka sedikit demi sedikit anak-anak mulai merasa kecanduan atau mulai merasa ketergantungan akan media komunikasi tersebut, secara tidak langsung hal-hal tersebut membawa perubahan-perubahan dalam kehidupan individu maupun masyarakat luas sehingga membawa 
dampak yang sangat serius seperti anak-anak menjadi kecanduan atau ketergantungan terhadap penggunaan media komunikasi.

Teori ketergantungan media atau Dependensi theory menyatakan bahwa semakin seseorang tergantung pada suatu media untuk memenuhi kebutuhannya, maka media tersebut menjadi semakin penting untuk orang atau individu tersebut.

Tingkatan ketergantungan media dipengaruhi oleh:

1. Kapasitas media untuk memenuhi kebutuhan individu sebanyak mungkin. Individu akan semakin tergantung pada media jika media tersebut dapat memenuhi sejumlah besar kebutuhan khalaayak dibandingkan dengan media yang memberikan sedikit saja kebutuhan khalayak.

2. Stabilitas sosial. Dalam periode perubahan yang intens seperti terjadinya konflik sosial dan lain-lain, setiap individu terpanggil untuk mengevaluasi kembali nilai, keyakinan, dan praktik mereka serta mempertimbangkan pilihan dan perilaku baru. Dalam situasi seperti itu, tingkat ketergantungan pada media akan meningkat secara signifikan karena ada kebutuhan yang sangatkuat akan saran ataupun dukungan.

3. Sebagai komponen yang aktif dalam proses komunikasi, khalayak memilih media yang paling di sukai berdasarkan kebutuhan individu dan faktor-faktor eksternal lainnya. Dalam artian, khalayak akan menjadi kurang tergantung pada media jika tidak lagi ada media ataupun non media alternatif yang dapat memenuhi kebutuhannya.

4. Sejumlah media dan non media alternatif tergantung pada sifat psikologis individu dan dibatasi oleh beberapa faktor eksternal ketersediaan media dan lain-lain.

Menurut teori dependensi media atau ketergantungan media, media sadar akan kemampuannya menciptakan hubungan ketergantungan dengan khalayak dan menggunakan kekuatannya untuk mencaoai tujuan. Hubungan ketergantungan media ini dibentuk mulai dari empat tahapan, yaitu:

1. Individu tertarik pada media yang menawarkan berbagai konten yang dapat memenuhi kebutuhan mereka tentang pemahaman, informasi, dan hiburan.

2. Hubungan ketergantungan dimulai dengan intensitas yang berbeda. Semakin tinggi intensitasnya maka akan semakin tinggi rangsangan kognitif dan afektif. Rangsangan kognitif berfungsi untuk meningkatkan dan mempertahankan perhatian individu sedangkan rangsangan afektif berfungsi untuk meningkatkan tingkat kepuasan individu.

3. Kedua rangsangan ini kemuadian mengaktifkan pemrosesan dan penghafalan informasi

4. Keterlibatan yang besar mungkin semakin meningkatnya efek media pada individu di tingkat kognitif, afektif, dan perilaku dalam jangka panjang.

Demikian teori di atas menggambarkan bahwa betapa media mempengaruhi tingkat kecanduan anak-anak dalam penggunaan media komunikasi, karena media memberikan kebutuhan-kebutuhan yang dirasa bisa memenuhi kebutuhan anak dalam kehidupan sehari-hari, akan tetapi hal ini bisa dihindari apabila orang tua berperan aktif dalam memantau dam membimbing perkembangan dan perubahan perilaku anak, karena orang tuan adalah suatu hal terpenting dan utama terhadap perkembangan kepribadian dan pertumbuhan jati diri seorang anak. Hal yang paling melekat dalam suatu perkembangan anak adalah bimbingan dari keluarga terutama orang tua.

\section{KESIMPULAN}

Dari hasil penelitian dengan Dampak Media Sosial Terhadap Perilaku Sosial Anak di Kota Makassar, dapat kesimpulkan bahwa Media komunikasi telah menjadi sesuatu yang sangat dibutuhkan oleh masyarakat, dari masyarakat kelas atas sampai kelas bawah. Media komunikasi bukan lagi hal yang susah untuk diperoleh. Media komunikasi juga telah merambat pada kalangan semua kalangan dan usia dibuktikan dari maraknya penggunaan media komunikasi di lingkungan masyarakat bahkan remaja dan anak-anak. Tidak bisa dipungkiri bahwa anak-anak dan remaja paling 
rentan terjebak dalam pengaruh buruk media. Arus informasi dapat dengan cepat mempengaruhi perkembangan pola pikir anak yang mengarah pada perubahan pola perilaku anak.

Anak-anak dan remaja sangat dipengaruhi oleh muatan yang disediakan oleh media komunikasi. Penggunaan media komunikasi tidak hanya memberikan dampak positif saja akan tetapi juga memberikan dampak yang negatif yang dapat merugikan penggunanya terlebih pada anak yang cepat terpengaruh dan memiliki rasa ingin tahu yang tinggi, sehingga secara tidak langsung remaja atau anak-anak dapat mengakses sesuatu hal yang negatif atau yang tidak baik dan tidak sesuai dengan umur sang anak, ini dapat menyebabkan prestasi mereka menurun, rendahnya prestasi belajar, bahkan cenderung tidak mendengarkan apa yang orang tua mereka katakan, bahkan jika di biarkan terus menerus maka akan menjadi hal buruk bagi perkembangan sifat dan perilaku anak tersebut.

Dalam hal ini maka peran orang tua sangat lah penting dalam melakukan proses pengawasan dan memberikan pemahaman kepada anak dalam penggunaan media komunikasi dengan bijak sehingga hal-hal yang tidak di inginkan tidak terjadi pada remaja dan anak-anak, karena mengingat orang tua adalah lembaga pertama dalam pembentukan pola pikir, perilaku, dan karakter anak.

\section{DAFTAR PUSTAKA}

A, Baron, Robert dan Donn Byrne. (2003). Psikologi Sosial. Jakarta: Airlangga.

Al Hakim, Suparlan. (2015). Pengantar Studi Masyarakat Indonesia. Malang: Madani.

Badan Pusat Statistik. (2018). Kota Makassar dalam Angka. Makassar: BPS Kota.

Bungin, Burhan, (2011). Sosiologi Komunikasi. Jakarta: Prenada Media Grup.

Cangara, Hafied. (2014). Pengantar Ilmu Komunikas. Jakarta: PT Raja Grafindo Persada.

Effendy, Onong Uchjana. (1986). Dinamika Komunikasi. Bandung: PT Remaja Rosda Karya.

Halik, Abdul. (2013). Komunikasi Massa. Makassar: Alauddin University Press.

Ibrahim, Rusli. (2001). Pembinaan Perilaku Sosial Melalui Pendidikan Jasmani: Prinsip-Prinsip dan Metode.

Jones, Pip. (2003). Pengantar Teori-Teori Social: Dari Teori Fungsionalisme Hingga Post Modernisme. (trj.) Saifuddin. Jakarta: Pustaka Obor.

Liliweri, Alo. (2011). Komunikasi Serba Ada Serba Makna. Jakarta: Kencana.

Nisrima, Siti. (2016). Jurnal Ilmiah Mahasiswa Pendidikan Kewarganegaraan Unsyiah. Band Aceh.

Pranata Yusuf, Doni. (2017). Pengaruh Media Sosial Facebook Terhadap Pola Komunikasi

Interpersonal Di SDN IV Sudirman Makassar, (Skripsi Tidak Diterbitkan): Universitas

Hasanuddin Makassar.

Rachmat, Jalaluddin. (1994). Psikologi Komunikasi. Bandung: PT. Remaja Rosdakarya, Bandung.

Ritzer, George. (2011). Sosiologi Ilmu Pengetahuan Berparadigma Ganda. Jakarta: PT. Raja Grafindo Persada.

Ritzer, George. (2012). Teori Sosiologi Dari Sosiologi Klasik Sampai Perkembangan Terakhir

Postmoderen. Yogyakarta: Pustaka Pelajar.

Roslina, Ida. (2014). Dampak Media Komunikasi Terhadap Anak SD

(Studi Di Sdn Mojolangu 2 Malang), (Skripsi Tidak Diterbitkan): Universitas Muhammadiyah Malang.

Mukramin, Sam'un dan Suardi. (2017). Interelasi Tradisi-Modernisasi pada Masyarakat Towuti

Kabupaten Luwu Timur. Jurnal Equilibrium: Pendidikan Sosiologi, 71. Vol. V No. 1 Mei.

Soekanto, Soejono. (2007). Sosiologi Suatu Pengantar. Jakarta: PT. Grafindo Persada.

Sugiyono. (2003). Metode Penelitian Kuntitatif,Kualitatif dan R\&D. Bandung: Alfabeta.CV.

Tim Penyusun Kamus Pusat Bahasa. (2003). Kamus Besar Bahasa Indonesia. Jakarta: Balai Pustaka.

Upe, Ambo. (2010). Tradisi Aliran dalam Sosiologi dari Filosofi Positifistik ke Post Positivistik. Jakarta:

PT. Raja Grafindo Persada.

. (2018). https://www.google.co.id/image/peta-tata-ruang-kota-makassar.

(2018). https://pakarkomunikasi.com/teori-dependensi-dalam-komunikasi-massa. 